\title{
DISCURSO DE ÓDIO E DIGNIDADE HUMANA: UMA ANÁLISE DA REPERCUSSÃO DO RESULTADO DA ELEIÇÃO PRESIDENCIAL DE 2014
}

\author{
HATE SPEECH AND HUMAN DIGNITY: \\ AN ANALYSIS ON THE REPERCUSSION OF THE 2014 \\ PRESIDENTIAL ELECTION RESULTS
}

Mariana Jantsch de Souza*

Para uma democracia, a recusa do outro e o irracionalismo são perigosos, idualmente mortais

(TOURAINE, 1996, p. 176)

\section{RESUMO}

Neste texto, buscamos compreender a discursivização do resultado eleitoral de 2014. Para tanto, nos detemos na análise de discursividades que nascem atreladas à ideia de democracia por repercutirem o evento que marca o ápice da vida democrática e, também, porque põem em questão o papel de cada sujeito no funcionamento desse sistema. Nosso foco são práticas discursivas que põem em movimento discriminações e intolerâncias ao outro em função de um resulto eleitoral indesejado por uma parcela da população. Trata-se de um discurso que revela visões hierarquizadas e hierarquizantes da sociedade brasileira. Com essa leitura ancorada na teoria de Michel Pêcheux, observamos o discurso de ódio que emerge em meio a um processo de rejeição e de destituição da Presidenta eleita, processo esse que produz efeitos em cascata. São, pois, discursividades que tomam como alvo de ódio parte da população (os nordestinos), a Presidenta e, por fim, a democracia. Com seus desdobramentos e seu funcionamento, essas práticas discursivas atingem a dignidade de parte dos brasileiros.

Palavras-chave: Eleição presidencial de 2014; Discurso de ódio; Dignidade humana.

\section{ABSTRACT}

In this text, we seek to understand the discursivization of the electoral result of 2014. To this end, we focus on the analysis of discursivities that are born linked to the idea of democracy because they reverberate the event that marks the climax of democratic life and also because they call into question the role of each individual in the functioning of this system. Our

\footnotetext{
* Instituto Federal de Educação, Ciência e Tecnologia Sul-rio-grandense (IFSul)/ Universidade Católica de Pelotas, Pelotas (RS), Brasil. marianajsouza@yahoo.com.br.
} 
focus is on discursive practices that set in motion discriminations and intolerances to the other due to an undesired electoral outcome for a portion of the population. It is a discourse that reveals the hierarchical visions of Brazilian society. With this reading anchored in the theory of Michel Pêcheux, we observe the hate speech that emerges amid a process of rejection and removal of the elected President, a process that produces cascade effects. Therefore, they are discourses that take as a target of hatred part of the population (the Northeastern), the President and, finally, democracy. With their unfolding and functioning, these discursive practices strike the dignity of Brazilians.

Keywords: 2014 Presidential Election; Hate Speech; Dignity.

\section{CONSIDERAÇÕES INICIAIS}

Para estas reflexões, assumimos como posição ou lugar de análise a teoria da Análise de Discurso de tradição pecheuxtiana (AD). Em razão de seu objeto - o discurso -, entendido como um nó, como "o lugar teórico em que se intrincam todas suas grandes questões sobre a língua, a história, o sujeito" (MALDIDIER, 2003 , p. 15), recorremos à $\mathrm{AD}$ para compreender o modo como foi discursivizado o resultado eleitoral por uma parcela da população brasileira. Esse horizonte teórico nos leva a considerar os aspectos sócio-históricos que se manifestam na/pela estrutura da língua. Ou seja, implica em ler e compreender as práticas discursivas em análise a partir das relações entre língua, história e ideologia em funcionamento no discurso.

Diante disso, configuramos o discurso em análise em uma formação discursiva (FD), nomeada como FD anti-Dilma ou FD1 e representativa de um discurso de não aceitação da diferença, posicionando-se contra a reeleição de Dilma Rousseff e contra seus supostos eleitores. Não desconsideramos o contradiscurso ${ }^{1}$ produzido para fazer frente aos movimentos de rejeição e ódio produzidos pelas práticas discursivas em análise, apenas tomamos como foco de nossas reflexões, neste texto, o discurso anti-Dilma produzido em repercussão ao resultado eleitoral.

As sequências discursivas que formam nosso dispositivo analítico, foram todas coletadas nas redes sociais pelo sítio eletrônico Notícias Terra e disponibilizadas

1. Essa pesquisa também contempla uma análise do referido contradiscurso, o qual é configurado em uma FD nomeado FD pró-Dilma ou FD2, considerada representativa de um discurso favorável à reeleição de Rousseff e de não aceitação de práticas discursivas inscritas no âmbito da FD1. Neste texto, não apresentamos a análise do discurso da FD2.

2. Fonte: $<$ http://noticias.terra.com.br/eleicoes/nordestinos-sao-hostilizados-apos-vitoria-de-dilmarousseff,aa13fc86bd059410VgnVCM5000009ccceb0aRCRD.html>. Acesso em: 27 out. 2014. 
como cobertura instantânea da repercussão da eleição presidencial, em especial nas redes sociais ${ }^{3}$.

Antes de prosseguirmos para as análises, é importante explicar um conceito essencial para essas reflexões: formação discursiva. Para Pêcheux, FD é "aquilo que, numa formação ideológica dada, isto é, a partir de uma posição dada numa conjuntura dada, determinada pelo estado de luta de classes, determina o que pode e deve ser dito" (2009a, p. 147). Trata-se de um constructo teórico, não é da ordem do empírico. É da ordem do imaginário: é, imaginariamente, o lugar de dizer em que o sujeito se inscreve no interior da FD. E este lugar de dizer está conformado em relação ao que é ou não aceito e conveniente no âmbito dos saberes da FD.

Para Orlandi, a noção de FD "permite compreender o processo de produção de sentidos, a sua relação com a ideologia e também dá ao analista a possibilidade de estabelecer regularidades no funcionamento do discurso" (2013, p. 43). Pensar as FDs em que se inscrevem os dizeres em análise permite observar a ideologia funcionando, pois as FDs representam as Formações Ideológicas (FI) que lhes são correspondentes: "diremos que os indivíduos são 'interpelados' em sujeitos falantes (em sujeitos do seu discurso) pelas formações discursivas que representam 'na linguagem' as formações ideológicas que lhes são correspondentes" (PÊCHEUX, 2009a, p. 147). Por isso, entendemos que os sentidos são determinados idelogicamente; por isso, Pêcheux afirma que é a ideologia que fornece as evidências do sentido, que nos dá a ilusão de transparência da linguagem.

\section{DO DISCURSO ANTI-DILMA}

Em nossa pesquisa, tomamos como efeito de início do processo de rejeição e de destituição de Dilma Rousseff a repercussão negativa do resultado eleitoral de 2014, que produziu um movimento de rejeição aos eleitores de Dilma e à própria Presidenta. Ressaltamos que analisamos apenas um dos aspectos da repercussão do resultado eleitoral de 2014: a não aceitação da vitória de Dilma e a responsabilização de uma parcela da população brasileira por este resultado. Não estamos considerando que, no âmbito dessa FD, haja apenas essa postura extrema em relação à eleição presidencial de 2014. Estamos trazendo para nossa análise, num gesto de recorte, apenas esse modo de significar o acontecimento em pauta.

3. A utilização desse material em nossa pesquisa não necessita de autorizações especiais, pois se trata de material público em razão das circunstâncias de sua produção e divulgação. Mesmo assim, não são identificados seus autores, revelamos, apenas, o endereço eletrônico do meio digital em que tal material foi colhido. 
Para realizar esses propósitos de pesquisa, nos deteremos nas sequências discursivas que seguem, as quais, no decorrer do processo de análise, serão metodologicamente retomadas.

- sd 1 - LUTO!!! NORDESTINOS FDP !!! POVO BURRO QUE NÃO SABE ANALISA[r] ESSA MERDA DE DILMA FDP

- sd 2 - Esses nordestinos desgraçados são o câncer do país! E podem me processar se quiserem

- sd 3 - Só aqueles nordestinos malditos que votam na dilma nossa espero que nunca mais chova la seca pra sempre

- sd 4 - Nordestinos irão morrer na seca e burrice mesmoooo!!!!!!!

- sd 5-Hoje, qualquer suposto preconceito contra cariocas, nordestinos e baianos deixou de existir, porque virou Pós Conceito! Bando de fdp que destruíram nosso país e a economia por migalhas!

- sd 6 - Desejo do fundo do coração que sejam tomados pela desnutrição, que seus bebês nasçam acéfalos, que suas crianças tenham doenças que os médicos cubanos não consigam tratar, que o ebola chegue no Brasil pelo Nordeste e mate a todos! Só outra arca de Noé pra dar jeito!

- sd 7 - Mata esses nordestino fdp

- sd 8 - Se eu encontrar algum nordestino aqui em MG eu jogo fogo

- sd 9 - Se vc é nordestino e votou no Aécio, venha para o Sul, pq já encomendei uma macumba pra cair um meteoro aí e matar todos numa vez só... vsf... merda de povo idiota

- sd 10-O negócio é dividir o Brasil em 2... Dilma para o norte, nordeste e centro oeste...e Aécio para Sul e Sudeste... seria muito justo ... cada um ter o presidente que merece

- sd 11

$\operatorname{sd} 12^{4}$

Para a análise dessa discusividade, nosso olhar perpassa duas grandes questões que se entrecruzam: a historicidade desse discurso e o ódio que materializa. Por razões de organização textual, abordamos tais questões separadamente, mas consideramos que o ódio que emerge no discurso em pauta há muito já circula em nossa sociedade. Funciona como uma presença-ausência, como a análise do efeito fundador dessa discursividade explicita.

A tônica do discurso da FD anti-Dilma é, assim, o ódio ao outro, à democracia que permite que esse outro participe das tomadas de decisão coletiva. Com isso,

4. Mantivemos a grafia original de todas as sequências discursivas. 
está na base do funcionamento dessa discursividade a violência materializada na linguagem.

\section{DISCURSO E HISTORICIDADE: DO EFEITO FUNDADOR DO DISCURSO DA FD1}

Em $\mathrm{AD}$, entendemos que o discurso fundador "não se apresenta como já definido, mas antes como uma categoria do analista a ser delimitada pelo próprio exercício da análise [...] os discursos fundadores são discursos que funcionam como referência básica no imaginário constitutivo desse país" (ORLANDI, 2003, p. 7).

Dada a incompletude de todo e qualquer discurso, optamos por trabalhar com a noção de efeito fundador do discurso. A discursividade presente na FD anti-Dilma (e no conflito nela materializado) apresenta como efeito fundador o discurso de segregação da população brasileira em dois grupos que se opõem, segundo critérios geográficos. Isso porque a relação de antagonismo que se instaura no contexto discursivo em análise (repercussão do resultado eleitoral de 2014) faz emergir do interdiscurso o processo conflituoso de migração dos brasileiros do Norte e do Nordeste para as regiões Sul e Sudeste, ocorrido nas décadas de 1930 e 1940. Consideramos a migração de nortistas e nordestinos como referência básica do conflito que o discurso em análise retoma e reacende.

O discurso fundador faz surgir uma nova tradição de sentidos: "instala-se outra 'tradição' de sentidos que produz os outros sentidos nesse lugar. Instala-se uma nova 'filiação'. E esse dizer irrompe no processo significativo de tal modo que pelo seu próprio surgir produz sua 'memória"' (ORLANDI, 2003, p. 13). O processo que a migração em questão produziu estabeleceu, assim, um "novo sítio de significância", conforme Orlandi e, por isso, é por nós considerado efeito fundador, uma vez que

cria tradição de sentidos projetando-se para a frente e para trás, trazendo o novo para o efeito do permanente. Instala-se irrevogavelmente. É talvez esse efeito que o identifica como fundador: a eficácia em produzir o efeito do novo que se arraiga no entanto na memória permanente (sem limite). Produz desse modo o efeito do familiar, do evidente, do que só pode ser assim (ORLANDI, 2003, p. 13-4, grifamos).

O discurso que estamos tomando como fundador produz esse efeito do familiar, no sentido de que a relação entre esses brasileiros só pode ser assim, conflituosa, agressiva e em permanente estado de antagonismo. Passemos a entender como se instaurou essa relação.

A migração de nortistas e nordestinos para o Sudeste e Sul do país foi motivada pela busca de trabalho e melhores condições de vida, uma vez que essas 
eram as regiões brasileiras mais desenvolvidas e industrializadas na época. Segundo Paulo Fontes (2008), a migração inicia nos anos 1930, o conflito estabelece-se lentamente. Nas décadas de 1940 e 1950, a tensão entre os grupos se agrava. O autor mostra que esse movimento migratório foi visto, por parte dos paulistanos, como um problema desde o princípio, pois

a acelerada industrialização e o crescimento da cidade eram acompanhadas por um vertiginoso aumento dos problemas de infraestrutura urbana. Dificuldades de transporte, ausência de moradias, ampliação da criminalidade e da miséria urbana passaram, lado a lado, com o progresso e desenvolvimento da metrópole, a fazer parte do cotidiano de São Paulo. Para muitos setores da sociedade paulistana, longe de parceiros do desenvolvimento, os migrantes nordestinos eram considerados culpados e eventuais 'bodes expiatórios' pelas agruras advindas do rápido crescimento da cidade. Uma série de adjetivações e estereótipos a respeito dos trabalhadores migrantes nordestinos foi reiterada e forjada ao longo desse período (FONTES, 2008, p. 72, grifamos).

A cada novo problema social, prontamente os "culpados" eram identificados: os migrantes. Esse estigma foi consolidado no/pelo discurso, seja por meio de adjetivações que insistiam na desqualificação do migrante, seja por meio de um estereótipo desse outro indesejado sempre associado a problemas sociais.

Os jornais populares da época legitimavam e reproduziam essa visão negativa acerca dos nortistas e nordestinos. Em sua pesquisa, Fontes reproduz trechos de reportagens da época para ilustrar como a mídia teve papel determinante na consolidação e agravamento desse conflito. Os diversos jornais citados na pesquisa difundiam hostilidade aos trabalhadores migrantes e preconceito, reafirmando que "os migrantes eram considerados como o reflexo do 'baixo nível cultural e técnico da população do país" (FONTES, 2008, p. 73).

Assim, a rejeição dos paulistanos aos nordestinos frequentemente ganhava as folhas dos jornais em reportagens que, trabalhando no nível da repetibilidade, insistiam em efeitos de rejeição:

Uma extensa reportagem do popular diário paulistano A Hora em 1956 exemplifica bem essa visão negativa sobre os migrantes. A presença de nordestinos na cidade toma ares de uma verdadeira e assustadora invasão dos "mais desencontrados indivíduos [...] personas non gratas que vêm tentar sabotar o trabalho construtivo, decente e elevado dos bandeirantes" (FONTES, 2008, p. 73).

Os migrantes nordestinos, pública e reiteradamente considerados personas non gratas, eram homogeneizados numa estratégia para desqualificá-los e agredilos, pois "ao chegar a São Paulo, as diferenças entre os "nortistas" tenderam a ser homogeneizadas. Os diversos migrantes nordestinos e mineiros que chegaram a São Paulo no fim dos anos 1940 e durante os anos 1950 foram genericamente chamados de 'baianos"” (FONTES, 2008, p. 69). Portanto, esse movimento migratório vivido 
em São Paulo, o "centro nevrálgico do capitalismo industrial brasileiro", constituiu um processo contraditório que iniciou outro processo: o de preconceitos e de hostilização aos brasileiros das regiões Norte e Nordeste, segundo Fontes (2008, p. 68).

Esse é o pano de fundo interdiscursivo que sustenta os enunciados em análise, sendo aqui tomado como efeito fundador dos saberes que sustentam o discurso em pauta que retomam e alimentam a polarização dos brasileiros. Surge dessa relação conflituosa a responsabilização dos nordestinos pelos acontecimentos que se opõem aos saberes da FD que sustenta o discurso anti-Dilma, insistindo no estigma de bodes expiatórios. Seguindo esse caminho de significação do outro, em 2014, em razão do resultado eleitoral indesejado pelo enunciador desse discurso, esses sujeitos surgem recolocados em posição expiatória.

Uma das marcas discursivas que remonta ao conflito vivido no período de migração e que permite observar a presença desse efeito fundador no discurso da FD anti-Dilma é a excessiva adjetivação do sujeito nordestino. Nas sequências discursivas em análise, esse sujeito surge, no fio do discurso, para ser desqualificado a partir de termos como: $\mathrm{fdp}^{5}$ (sd 1, 5 e 7), povo burro (sd 1), câncer (sd 2), desgraçados (sd 2), malditos (sd 3), merda de povo idiota ( $\mathrm{sd}$ 9). Esse processo de desqualificação, nesse discurso, cumpre a função de demarcar as diferenças entre o sujeito enunciador e o outro (o sujeito nordestino), estabelecendo uma relação de superior versus inferior. No funcionamento dessa discursividade, esse processo é associado a um movimento de hostilização, para sustentar e justificar a recusa do outro, da liberdade e da igualdade do outro no que tange a sua atuação no processo democrático, em comparação (e em oposição) à atuação do sujeito enunciador do discurso em análise.

Desse modo, a excessiva desqualificação do nordestino é produzida para marcar uma relação maniqueísta entre dois polos: quem presta/quem não presta. O nordestino é significado para ocupar o polo mal/negativo dessa relação e, por isso, merece ser rejeitado, hostilizado e excluído do grupo a que pertence o sujeito enunciador. De outro lado, este sujeito, ao marcar a desqualificação do outro nessa direção, se posiciona no polo oposto dessa relação maniqueísta: no lado do bem/ positivo.

Esses excessos colaboram para a construção do antagonismo entre essas posições-sujeito. Um efeito de sentido que começa com qualificações negativas, avança, intensificando-se, saturando-se, até tornar-se um efeito de exclusão e de segregação, consolidando um discurso de ódio. $\mathrm{O}$ outro não é digno de existir,

5. Sigla para a expressão "filho da puta". 
devendo ser morto ou excluído do Brasil, pois representa o próprio mal que aflige a nação (é o câncer, é maldito, é desgraçado). Nesse percurso de significação, apenas os sujeitos que se inserem no domínio de saber da FD anti-Dilma seriam dignos de pertencer à nação brasileira.

Os nordestinos, no início do século XX, eram considerados a parcela da população brasileira que representava o baixo nível cultural e social, pessoas non gratas que sabotavam "o trabalho construtivo, decente e elevado". Esse discurso, no contexto da discursividade em análise, aparece (re)significado em enunciados do tipo "Só outra arca de Noé pra dar jeito!" (sd 6). E, segundo esse ponto de vista, os nordestinos mereceriam ser aniquilados da espécie humana: "cair um meteoro aí e

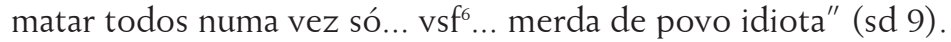

Portanto, o discurso do início do século XX volta a trabalhar, atualizando-se e produzindo efeitos de sentido em relação ao processo democrático e à atuação dos nordestinos na sociedade brasileira do século XXI: novos problemas sociais e condições de produções distintas fazem ressurgir, com maior intensidade, velhos dizeres. Com isso, os saberes da FD anti-Dilma resgatam um passado discursivo em que os nordestinos são a origem dos problemas do Brasil, havendo, por trás disso, dois 'Brasis': o dos nordestinos e o Brasil dos sujeitos filiados à FD anti-dilma.

Atualizados, esses efeitos de sentido produzem uma nova culpabilização dos nordestinos. Responsabilizá-los pelo resultado indesejado por uma parcela da população, em relação à eleição presidencial, restabelece uma responsabilização mais profunda: a origem dos problemas do Brasil - no imaginário do sujeito enunciador do discurso da FD anti-Dilma - seria acolher os nordestinos (esse outro indesejado), seria o contato/convívio com o diferente, com sujeitos que não se filiam a mesma rede discursiva. Seria, também, compartilhar o mesmo espaço, os mesmos direitos, a mesma nação com esses sujeitos. Pelo funcionamento dessas práticas discursivas, compreendemos que o nordestino é um outro que não é considerado como igual e que não deve ser livre, pois quando livre usa sua liberdade na direção oposta aos interesses e saberes da FD anti-Dilma.

\section{DO DISCURSO DE ÓDIO: CONSIDERAÇÕES TEÓRICAS}

Os discursos que materializam intolerâncias, discriminações e ódios em circulação social inserem-se num movimento sócio-histórico no qual a relação com outro é tomada como relação de antagonismo e não como uma relação de

6. Sigla para a expressão "vai se fuder". 
interlocução. O contato com outro instaura-se pelo viés do confronto e disso resulta a aversão à diferença, materializada em práticas discursivas que produzem efeitos de hostilização e ódio. Por isso, nesse discurso, o outro surge como alvo e não como interlocutor.

Esse caminho nos leva a pensar sobre a discursivização de relações antagônicas na sociedade brasileira atual, sobre a maneira dicotômica e hierarquizada de materializar as relações de força subjacentes a essas práticas discursivas. Pôr em questão o discurso de ódio diz respeito, sobretudo, aos limites dos direitos de liberdade de expressão; à forma como é engendrada a relação eu/outro; à forma como circulam em nossa sociedade os valores liberdade e igualdade. Diz respeito, portanto, a pensar sobre dignidade e direitos humanos.

Diante disso, nossa discussão leva em conta os valores essenciais ao regime democrático por considerar que o discurso de ódio, em análise, produz efeitos de intolerância à diferença, restringindo o alcance desses valores. Assim, ao afetar os eixos que estruturam o regime democrático, os efeitos produzidos por esse discurso interferem no próprio processo democrático.

A democracia, por ser uma forma específica de organizar a sociedade, implica certos pressupostos e põe em movimento certos fins, os quais a caracterizam de fato (Cf. BOBBIO, 2014, p. 38). Em síntese, toda essa forma própria de organização social pressuposta pelo regime democrático não é apenas para tomar decisões coletivas, para gerir a res pública, para promover a participação ativa de cada cidadão; toda essa ordem específica é orientada para a construção de uma sociedade igualitária, baseada no valor liberdade. Portanto, quando tratamos de democracia, tratamos de liberdade e de igualdade, considerando-os valores que se implicam reciprocamente.

Essa forma de pensar a noção de democracia nos ajuda a compreender o funcionamento que discursos de ódio assumem quando põem em movimento a intolerância ao outro no que tange a sua participação no processo democrático. O discurso de ódio, ou bate speech, funciona a partir de um modo desigual de relação entre eu (sujeito enunciador) e outro, em que o primeiro é tido como superior e o segundo inferior e, por isso, alvo de intolerâncias, discriminação e ódio.

No âmbito jurídico, o bate speech é discutido, especialmente, na seara constitucional, quando se pensam os limites da liberdade de expressão. A discussão centra-se na distinção entre liberdade de expressão (que fica no nível da opinião, do pensamento) e ofensa a direitos de terceiros, o que configura um ato ilícito, na esfera cível, e/ou crime, na esfera penal. Para tratar de ilícito de natureza cível, recorre-se à definição prevista no art. 187, CC, segundo a qual "também comete ato ilícito o titular de um direito que, ao exercê-lo, excede manifestamente os limites impostos 
pelo seu fim econômico ou social, pela boa-fé ou pelos bons costumes" (BRASIL, Código Civil, grifamos).

Considerando essa definição, podemos pensar, incialmente, que o discurso de ódio nasce, do ponto de vista jurídico, de um excesso. O excesso de liberdade de expressão, aliás, um excesso no uso, no exercício de um direito legítimo (o direito fundamental de liberdade). Mas que tipo de excesso é esse?

É um transbordar da liberdade; é exceder os seus limites e entrar na zona da ofensa, da violência contra o outro. Segundo Winfried Brugger, "o discurso do ódio refere-se a palavras que tendem a insultar, intimidar ou assediar pessoas em virtude de sua raça, cor, etnicidade, nacionalidade, sexo ou religião, ou que têm a capacidade de instigar violência, ódio ou discriminação contra tais pessoas" (2007, p. 118, grifamos). Para este autor, o bate speech centra-se em ações nucleares expressas pelos verbos insultar, intimidar, assediar e instigar como carga imediata, desse efeito primeiro surgem as consequências: violência, ódio, discriminação. São ações dirigidas a determinado grupo, como alvo, e contra o qual produzem os efeitos de violência.

Nessa mesma direção, Daniel Sarmento, entendendo que se trata de "um debate sobre os limites da tolerância" (2006, p. 39), afirma que o discurso de ódio se configura como: "manifestações de ódio, desprezo ou intolerância contra determinados grupos, motivadas por preconceitos ligados à etnia, religião, gênero, deficiência física ou mental ou orientação sexual, dentre outros fatores" (2006, p. 2).

Ainda no âmbito das discussões jurídicas, podemos entender, considerando os dois autores citados, que o discurso de ódio, como uma expressão discursiva, envolve dois elementos: externalidade e discriminação, conforme explica SILVA et al. (2011). Isso porque "discurso não externado é pensamento, emoção, o ódio sem o discurso" (SILVA et al., 2011, p. 447), ou seja, quando não manifestado, não ultrapassa o plano abstrato dos pensamentos. É preciso linguagem para conferir materialidade a esse ódio e fazê-lo transbordar o nível das emoções e tornar-se discurso. Ao ser materializado, o ódio é posto em movimento: ao tornar-se discurso, torna-se ação ${ }^{7}$ e, assim, produz efeitos/consequências de violência e discriminação. Esses efeitos decorrem de uma característica essencial do hate speech: "É uma manifestação segregacionista, baseada na dicotomia superior (emissor) e inferior (atingido) e, como manifestação que é, passa a existir quando é dada a conhecer

7. Conforme a Teoria dos Atos de Fala, de Austin, considerando as três dimensões integradas dos atos de fala (locucionário, ilocucionário e perlocucionário), dizer é realizar uma ação: o discurso é ação. Ao tratar de discurso de ódio, pensamos, sobretudo, nas duas últimas dimensões referidas. 
por outrem que não o próprio autor" (SILVA et al., 2011, p. 447). É dizer, subjaz a esse funcionamento a suposição de uma desigualdade essencial entre os polos em embate nesse discurso.

O grupo alvo da intolerância é significado, nesse discurso, como inimigo comum: "ao eleger o destinatário como inimigo comum incita a violência e seu extermínio, o que fere frontalmente o valor que serve de sustentáculo para o Estado Democrático de Direito, qual seja, a dignidade da pessoa humana" (SILVA; BOLZAN, 2012, p. 3). Por esse caminho, observamos a extensão e gravidade da questão do discurso de ódio, que põe em ação a desvalorização do outro e de sua dignidade. Em nosso sistema constitucional, a dignidade é considerada 'o princípio dos princípios' e surge na Constituição Federal como um dos fundamentos de nossa República:

Art. $1^{\circ}$ A República Federativa do Brasil, formada pela união indissolúvel dos Estados e Municípios e do Distrito Federal, constitui-se em Estado Democrático de Direito e tem como fundamentos:

[...]

III - a dignidade da pessoa humana;

A dignidade humana está posta, em nossa ordem jurídica, como valor central. Com isso, todo sistema jurídico é orientado para a promoção e proteção da pessoa, sendo a dignidade significada juridicamente como um "princípio profundamente humanista, baseado na valorização da pessoa e comprometido com a garantia dos seus direitos básicos contra todas as formas de injustiça e opressão" (SARMENTO, 2016, p. 15). Assim, o respeito à dignidade surge como principal argumento capaz de coibir discursos de ódio e impedir que a liberdade de expressão funcione como mecanismo de proteção às injustiças e violências que esses discursos põem em movimento.

Deslocando essas considerações para o campo dos estudos da linguagem, compreendemos o discurso de ódio como violência simbólica. Entendemos essa noção tal como propõe Slavoj Žižek (2014) ao refletir sobre as diferentes dimensões da violência e suas causas. Para o autor, a violência nossa de cada dia pode ser subjetiva ou objetiva. A primeira dimensão da violência é a forma mais visível, claramente identificável, é aquela que salta aos olhos porque "é percebida como uma perturbação do estado de coisas 'normal' e pacífico"8 (2014, p. 17-8). Já a violência em sua dimensão objetiva "é precisamente aquela inerente a esse estado 'normal' de coisas. [...] é uma violência invisível, uma vez que é precisamente ela que sustenta a normalidade do

8. Como exemplo de violência simbólica o autor cita guerras, massacres, atos de terror, sendo uma forma de violência que deixa marcas bem concretas e visíveis. 
nível zero contra a qual percebemos algo como subjetivamente violento" (2014, p. 18). A violência objetiva se realiza como violência simbólica ou como violência sistêmica. Essas são as formas de violências sob a perspectiva de Žižek.

Em sua forma sistêmica, a violência objetiva "consiste nas consequências muitas vezes catastróficas do funcionamento regular de nossos sistemas econômico e político" (2014, p. 17). Quase invisível, esta violência está impregnada na estrutura social capitalista baseada nas relações de desigualdade-subordinação. É ela que ajuda a manter o status quo do sistema de relações sociais.

De outro lado, a violência simbólica é aquela "encarnada na linguagem":

essa violência não está em ação apenas nos casos evidentes - e largamente estudados - de provocação e de relações de dominação social que nossas formas de discurso habituais reproduzem: bá uma forma ainda mais fundamental de violência que pertence à linguagem enduanto tal, à imposição de um certo universo de sentido (ŽZIŽEK, 2014, p. 17, grifamos).

O discurso de ódio expõe esta imposição de um certo universo de sentido. É por isso que desperta a atenção: porque faz emergir a violência por trás do estado normal de coisas e a intolerância com aqueles que desvirtuam/subvertem esse universo de sentidos. Esse tipo de discurso mostra que esse estado normal de funcionamento de nossa sociedade é baseado na relação superior/inferior e insiste que essa ordem deve ser respeitada. Quando essa normalidade não é observada emerge a intolerância, a discriminação, a hostilização materializada em discursos de ódio.

A violência simbólica opera no âmbito ideológico: encarna-se na linguagem para impor a reprodução das relações de dominação/subordinação. $\mathrm{O}$ discurso de ódio, ao sustentar-se na dicotomia superior/inferior, trabalha impondo e/ou lembrando o lugar de cada um na estrutura social; baseia-se na naturalização dessa relação dicotômica e dessa determinação de lugares. Atua perpetuando relações sócio-históricas de desigualdade-subordinação a partir da face mais intolerante que a dominação ideológica pode assumir.

\section{DA VIOLÊNCIA SIMBÓLICA ENCARNADA NO DISCURSO ANTI-DILMA: SOBRE O ÓDIO NA/À DEMOCRACIA BRASILEIRA}

Estamos considerando que a discursividade da FD anti-Dilma se caracteriza como discurso de ódio porque, ao significar os nordestinos como culpados pelo resultado da eleição presidencial, instiga a intolerância e a discriminação contra esse grupo de eleitores, buscando excluí-los da nação e bani-los da fruição dos direitos de 
liberdade e de igualdade. Com esse funcionamento, e observando as regularidades desse discurso, entendemos que a violência contra o sujeito nordestino materializada nesse discurso instaura um processo de violências que se inicia com a culpabilização desse sujeito, passa pela sua punição e tem como desfecho com a imposição de uma 'solução' para o conflito: dividir o Brasil. No quadro abaixo, apresentamos cada um desses movimentos e as sequências discursivas que os representam:

Quadro 1. Do processo de violências e seus movimentos.

\begin{tabular}{|l|l|}
\hline \multicolumn{2}{|c|}{ Processo de violências contra o sujeito nordestino no discurso anti-Dilma } \\
\hline Movimento 1 - Culpabilização & $\operatorname{sd~1,sd~2,sd~3,sd~4,~sd~5~}$ \\
\hline Movimento 2 - Punição & $\operatorname{sd~6,sd~7,sd~8,~sd~9~}$ \\
\hline Movimento 3 - Imposição de uma solução para o conflito & $\operatorname{sd~} 10, \operatorname{sd~11,~sd~12~}$ \\
\hline
\end{tabular}

Os movimentos acima referidos, foram por nós nomeados e relacionadas a determinadas sequências discursivas conforme a preponderância desses efeitos de violência. Entendemos que esses movimentos ocorrem como degraus sucessivos na escala de violências configurada, pois um movimento anterior produz um efeito de sustentação em relação ao próximo, permitindo que o mesmo se instaure. Ou seja, o movimento de culpabilização sustenta os próximos movimentos, por exemplo.

Levando em conta a historicidade do conflito em discussão e seu efeito fundador, ressaltamos que, neste trabalho, estamos entendendo o termo nordestino de forma ampla: o nordestino, no discurso da FD anti-Dilma, representa o outro que não é aceito, a diferença que causa ojeriza e com a qual não se quer ter contato. Tal movimento por trás do uso desse termo pode ser observado em sequências em que são referidas outras regiões brasileiras:

- sd 5 - "Hoje, qualquer suposto preconceito contra cariocas, nordestinos e baianos deixou de existir, ..."

- sd 10 - "... Dilma para o norte, nordeste e centro oeste..." (grifamos).

A partir desse contexto e com a carga discursiva explicitada, mantemos o uso da palavra nordestino, pois foi a mais utilizada no discurso em análise. Porém, para nossas reflexões, tal expressão representa o sujeito que não partilha da mesma rede de saberes do sujeito enunciador de discurso da FD anti-Dilma. Passeamos a análise desses movimentos de violência.

\section{DA CULPABILIZAÇÃO}

Nesse primeiro movimento de violência contra os nordestinos, o discurso anti-Dilma se ocupa, principalmente, de identificar e caracterizar esse sujeito 
indesejado para apresentá-lo como alvo de violências, de ódio. Tal se realiza a partir de um processo de adjetivação do outro, que funciona para desqualificá-lo, marcando a superioridade do sujeito enunciador e assentando a culpabilização do sujeito nordestino nessa caracterização negativa.

Vejamos nossas sequências discursivas, grifamos os adjetivos e eventuais substantivos com valor de adjetivo:

- sd 1 - LUTO!!! NORDESTINOS FDP !!! POVO BURRO QUE NÃO SABE ANALISA[r] ESSA MERDA DE DILMA FDP

- sd 2 - Esses nordestinos desgraçados são o câncer do país! E podem me processar se quiserem

- sd 3 - Só aqueles nordestinos malditos que votam na dilma nossa espero que nunca mais chova la seca pra sempre

- sd 4 - Nordestinos irão morrer na seca e burrice mesmoooo!!!!!!!

- sd 5 - Hoje, qualquer suposto preconceito contra cariocas, nordestinos e baianos deixou de existir, porque virou Pós Conceito! Bando de fdp que destruíram nosso país e a economia por migalhas!

Do ponto de vista gramatical, a partir de um critério morfo-sintáticosemântico, adjetivo é a palavra variável que serve para modificar o substantivo9 . Há uma relação de dependência entre substantivo e adjetivo, em que o primeiro é o termo nuclear e o segundo é um termo subordinado ao principal. Sob o aspecto sintático, o adjetivo qualificativo pode assumir as funções de adjunto adnominal ou complemento predicativo. São termos ou locuções que se agregam ao substantivo e seu sentido é produzido sempre em relação ao termo principal, são um desdobramento desse.

A partir desse funcionamento dos adjetivos, o sujeito nordestino é vinculado a uma gama de características negativas que o identificam e o significam como um sujeito ruim por natureza. Para marcar sua culpabilização, o outro é significado como alguém burro, desgraçado, câncer, maldito, fdp, povo burro. É tomado como um sujeito intelectualmente incapaz ("que não sabe analisa[r] essa merda de Dilma $\mathrm{fdp}^{\prime \prime}, \mathrm{sd}$ 1), o que funciona para justificar a não aceitação desse sujeito, de seu voto e de seu poder de influenciar na democracia brasileira.

É a adjetivação que permite esse modo de significar o outro e a insistência no uso desse recurso funciona buscando estabilizar esse caminho de produção de

9. Conforme Macambira (1978, p. 38), Cunha e Cintra (2013, p. 259). 
sentido: o nordestino só pode ser significado assim. Pelo excesso (cf. Ernst, 2009), então, há a imposição de um universo de significação, para retomar Žižek (2014).

Esse processo excessivo de adjetivação do outro produz uma relação de causa e efeito no âmbito dos saberes que regulam o discurso em análise: a causa é ser mal/ruim e o efeito é ser hostilizado, rejeitado, agredido. Com isso, o nordestino seria a própria causa das violências de que é alvo, pois é burro, maldito etc. E a culpa retorna para esse sujeito: culpado pelo resultado eleitoral, culpado pelos problemas da nação e culpado por ser alvo desse discurso violento.

E, diante desse quadro, o nordestino é significado como um sujeito que não pode superar essas características, portanto, não tem como redimir-se: "irão morrer na seca e burrice mesmoooo!!!!!!!" (sd 4). Sendo assim, para o enunciador desse discurso, o nordestino seria um caso perdido, insolúvel.

Nesse processo discursivo, o resultado da eleição presidencial significa a destruição do país: "Bando de fdp que destruíram nosso país e a economia por migalhas!" (sd 5). E, por isso, faz com que o sujeito enunciador se entenda em estado de luto, conforme sd 1. Assim, a atuação, no processo democrático, dos sujeitos que não se filiam aos saberes da FD1anti-Dilma não é considerada válida e, tampouco, em consonância com as regras do jogo democrático, é um prejuízo à nação. Os sujeitos responsabilizados pelo resultado eleitoral não tiveram sua liberdade reconhecida e, também, não foram tratados de modo igual aos eleitores que assumiram posicionamento diferente.

Esse discurso insiste na validade e legitimidade apenas dos saberes da FD que o regula, pois, ao não aceitar o outro e as diferenças de posicionamento políticoideológico, do que resulta a reeleição de Dilma, funciona como uma forma de reiteração incessante de saberes interdiscursivos que se alinham ao discurso da FD anti-Dilma. Essa reiteração pode ser entendida como uma insistente afirmação de que existe um grupo de eleitores superiores e um grupo de eleitores inferiores, premissa que está na base do funcionamento do discurso de ódio. No primeiro grupo estão os eleitores filiados à FD anti-Dilma, no segundo estão os que não se inscrevem nessa mesma rede de filiação e, por isso, são alvo do discurso de ódio.

É este panorama que nos permite compreender que a discursividade em pauta põe em funcionamento o que Žižek entende como violência simbólica. Pois, esse discurso impõe 'um certo universo de sentido', em conformidade com os saberes de sua rede discursiva e insiste na dominância desses saberes e sentidos. Como o outro (representado na figura do nordestino) não se posiciona em conformidade com esses saberes e produz efeitos de sentido antagônicos, rompendo com o universo de sentidos aceitos pela FD anti-Dilma, esse outro surge como alguém inferior, alvo 
de intolerâncias e discriminação. E, assim, nessa discursividade, não se instaura uma interlocução com esse sujeito, que se torna apenas alvo desse discurso.

De outro lado, atentamos para a recorrência desse ódio ao nordestino no contexto de repercussão de resultados eleitorais. A sequência 2 nos traz uma pista do retorno dessa hostilização, recuperada pela categoria da memória, pois emerge na linearidade do discurso sob a forma de discurso transverso:

- sd 2 - Esses nordestinos desgraçados são o câncer do país! E podem me processar se quiserem (grifamos).

Tratar o outro como "desgraçado" e "câncer" do país remete a um préconstruído que emerge como discurso transverso: faz eco aí o que já havia sido discursivizado na década de 30 do séc. XX. Ou seja, toda a caracterização do sujeito nordestino que sustenta o efeito de culpabilização retoma pré-construídos observados no discurso tomado como efeito fundador da discursividade em pauta. O ódio ao nordestino já circula em nossa sociedade há muito e, de tempos em tempos, ressurge em discursos que retomam esse processo de significação do outro em níveis de intolerância e violência.

Após produzir esse efeito de hostilização aos nordestinos, considerando-os o mal que aflige a nação (câncer), em "E podem me processar se quiserem", emerge, no nível da formulação, a antecipação de um efeito de sentido já produzido em outras condições de produção na exterioridade da FD. São antecipados efeitos de sentido de reprovação à prática discursiva do sujeito enunciador e aos saberes da FD1.

Pêcheux ensina, em Análise Automática do Discurso (AAD-69), que todo processo discursivo "supõe, por parte do emissor, uma antecipação das representações do receptor, sobre a qual se funda a estratégia do discurso" (2010, p. 83). Trata-se do mecanismo da antecipação, pelo qual podemos observar que

o que funciona nos processos discursivos é uma série de formações imaginárias que designam o lugar que $\mathrm{A}$ e B se atribuem cada um a si e ao outro, a imagem que eles se fazem de seu próprio lugar e do lugar do outro. Se assim ocorre, existem nos mecanismos de qualquer formação social regras de projeção, que estabelecem as relações entre as situações (objetivamente definíveis) e as posições (representações dessas situações) (PÊCHEUX, 2010, p. 81-2).

Por esse mecanismo, o sujeito enunciador (A) antecipa-se ao dizer de seu interlocutor (B), num jogo que se estabelece a partir das imagens, representadas no discurso, do lugar que A atribui a cada um. Dessa forma, a antecipação também nos permite observar o diálogo entre os dizeres mobilizados no processo discursivo em que se inscreve o sujeito A. 
Nesse mesmo percurso de compreensão, Orlandi explicita a antecipação como uma estratégia argumentativa. A autora entende que a antecipação discursiva evidencia que

todo sujeito tem a capacidade de experimentar, ou melhor, de colocar-se no lugar em que o seu interlocutor "ouve" suas palavras. Ele antecipa-se assim a seu interlocutor quanto ao sentido que suas palavras produzem. Esse mecanismo regula a argumentação, de tal forma que o sujeito dirá de um modo, ou de outro, segundo o efeito que pensa produzir em seu ouvinte. [...] Dessa maneira, esse mecanismo dirige o processo de argumentação visando seus efeitos sobre o interlocutor (ORLANDI, 2013, p. 39).

Trata-se, assim, de um jogo de representações imaginárias, ou seja, é "a maneira como o locutor representa as representações de seus interlocutores e viceversa" (ORLANDI, 2011, p. 158). Conforme Pêcheux, esse jogo estabelece-se entre formações imaginárias, pois são elas que fornecem as representações, projetadas no discurso, do lugar atribuído a cada interlocutor. $\mathrm{O}$ funcionamento desse mecanismo parte de processos discursivos anteriores, sendo determinado pelo atravessamento de já ditos, conforme Pêcheux (2010, p. 85).

Para que o sujeito enunciador antecipe efeitos de sentido que imagina que seu interlocutor produzirá é preciso mobilizar já ditos: elementos exteriores recortados do interdiscurso e capazes de sustentar esse jogo de representações imaginárias. Mas essa relação entre o sujeito enunciador e o interdiscurso não é aleatória, é regulada pela $\mathrm{FD}$, de forma que as possibilidades e impossibilidades de retomadas de elementos interdiscursivos são determinadas pelo que pode, deve ou convém ser dito em dada FD. Assim, pelo mecanismo da antecipação o sujeito enunciador traz para o nível da formulação elementos de saber capazes de reforçar seu discurso, como numa estratégia argumentativa de convencimento.

É este processo que emerge na sd 2 em "E podem me processar se quiserem". O sujeito enunciador antecipa-se à reprovação que seu discurso pode causar alhures e marca sua indiferença a essa reação. Esta é a representação imaginária que o sujeito do discurso faz de seu interlocutor e, pela antecipação, a projeta em seu dizer.

Nessa sequência, esses aspectos podem ser pensados como a emergência de um pré-construído, sob a forma de discurso transverso, na linearidade do discurso sem marca linguística, como retomada de já-ditos, resgatados via memória discursiva. Isso porque a relação que a sd 2 estabelece com o interdiscurso, consideradas as condições de produção do discurso da FD anti-Dilma, remete a uma situação discursiva muito semelhante.

Na eleição presidencial de 2010, em que Dilma Rousseff concorreu com José Serra, após divulgação do resultado oficial das eleições e confirmação da vitória 
de Dilma, também houve um movimento de responsabilização de uma parcela da população brasileira ${ }^{10}$ - os nordestinos, considerados os principais eleitores da candidata. Na época, a hostilização aos nordestinos também ocorreu no ambiente virtual. No entanto, o alcance da internet, em 2010, era muito mais restrito do que em 2014. Por isso, teve dimensões muito menores do que a vivenciada na eleição em pauta.

No entanto, ao trazer o discurso-outro para o intradiscurso é produzido um efeito de indiferença a esse outro e a seu discurso: "E podem me processar se quiserem" (sd2). Nesse funcionamento, ainda que o outro manifeste sua reprovação ao discurso da FD anti-Dilma, podendo até recorrer a um processo judicial para tanto, isso não será suficiente para calar ou alterar o discurso de ódio dessa rede discursiva. As reações externas são, portanto, irrelevantes para o sujeito enunciador.

Por fim, para encerrar a análise desse primeiro movimento de violência materializado no discurso analisado, ressaltamos que o sujeito nordestino, significado como alguém de natureza inferior e ruim, passa a ser o culpado pelos problemas da nação, e o principal deles, nessa perspectiva e nessa conjuntura, é ter Dilma como presidenta. Podemos compreender que as rejeições e violências materializadas nesse discurso, no primeiro movimento de violência, se voltam não apenas para o sujeito nordestino, mas também para o próprio sistema democrático. Dessa perspectiva, a democracia colaboraria para essa situação de destruição do país e da economia (cf. sd 5) e de luto (cf. sd1), porque permite que esse sujeito tão inferior e incapaz participe do jogo democrático e possa decidir os rumos da nação. É a democracia que abre espaço para que um representante de saberes adversos possa governar o país. E, assim, as violências observadas atingem diretamente o sujeito nordestino e, indiretamente, a presidenta Dilma e o próprio sistema democrático.

Esse movimento de culpabilização faz ressurgir a posição expiatória que é atribuída, por alguns brasileiros, aos nordestinos desde o período da migração, tomado como efeito fundador. Então, se no passado, do efeito expiatório decorria a responsabilização dos nordestinos pelos problemas cotidianos da urbanização; na sociedade contemporânea essa responsabilidade alcança níveis mais amplos, sendo estendida ao não reconhecimento do direito de participar do processo democrático;

10. Nesse movimento de ódio ao nordestino, em 2010, o caso que teve maior repercussão foi de uma estudante que postou na rede social Twitter, ao manifestar-se sobre a vitória de Dilma, o seguinte: "Nordestisto não é gente, faça um favor a Sp, mate um nordestino afogado!"; "AFUNDA BRASIL. Deem direto de voto pros nordestinos e afundem o pais de quem trabalha pra sustentar os vagabundos que fazem filho pra ganhar o bolsa 171". Conferir em: $<\underline{\text { http://exame.abril.com. }}$ br/brasil/justica-condena-jovem-que-ofendeu-nordestinos-no-twitter $/>_{i}<$ https://tecnologia. uol.com.br/noticias/redacao/2012/05/16/justica-condena-universitaria-por-preconceito-contranordestinos-no-twitter.htm $>$. Acessos em 22 set. 2015. 
não sendo reconhecida e aceita a participação desse sujeito no processo de escolha de representantes políticos. Trata-se, em última instância, do não reconhecimento da cidadania plena desses sujeitos, sendo-lhes negados os valores liberdade e igualdade e, por conseguinte, sua dignidade humana.

\section{DA PUNIÇÃO}

O segundo movimento observado no discurso em análise, no processo de violências contra o outro, é a consolidação de uma punição. Nesse momento, instaura-se um discurso punitivo a partir da culpabilização já consolidada. A punição apresentada nesse discurso é a pior possível: a morte/o extermínio, conforme podemos observar nas seguintes sequências discursivas (grifamos):

- sd 6 - Desejo do fundo do coração que sejam tomados pela desnutrição, que seus bebês nasçam acéfalos, que suas crianças tenbam doenças que os médicos cubanos não consigam tratar, que o ebola chegue no Brasil pelo Nordeste e mate a todos! Só outra arca de Noé pra dar jeito!

- sd 7 - Mata esses nordestino fdp

- sd 8 - Se eu encontrar algum nordestino aqui em MG eu jogo fogo

- sd 9 - Se vc é nordestino e votou no Aécio, venha para o Sul, pq já encomendei uma macumba pra cair um meteoro aí e matar todos numa vez só... vsf... merda de povo idiota

Todas as punições impostas nesse discurso convergem para o mesmo desfecho: a aniquilação do outro que não partilha das mesmas filiações do sujeito enunciador; que assume posicionamento político-ideológico oposto, que vota diferente e que, por isso, é responsável pela reeleição de Dilma. Não se trata de uma punição qualquer, é a mais extrema e definitiva das punições que existe na humanidade e deve se realizar de modo cruel, como um suplício infligido ao outro.

A morte é uma certeza que acompanha a todos nós, mas nessa situação a morte do outro deve ser antecipada, violenta e consequência da culpa que imposta. Há, pois, uma relação de causa e consequência com o primeiro movimento de violência (culpabilização), resgatada pelas condições de produção desse discurso. No caso da sd 9, essa relação causal é explicitada na linearidade do discurso, conforme observamos na seguinte paráfrase: se você votou no Aécio, não merece essa punição, venha para o Sul e salve-se; mas se votou na Dilma deve ser punido. 
Observando os modos de realização da punição imposta, temos um efeito de "terceirização" da morte do outro. Em quase todas as sequências, não é o sujeito enunciador que realiza a ação punitiva que busca impor ao sujeito nordestino. Por exemplo, na sd 6, as punições impostas ao sujeito nordestino não dependem de ações realizadas pelo sujeito do discurso. $\mathrm{O}$ mal imposto ao outro são suplícios físicos que se realizam como distúrbios de saúde, ou seja, que doenças aflijam esse sujeito e o levem a morte. Já na sd 9, temos "encomendei uma macumba para cair um meteoro aí e matar a todos de uma vez só": o que mata o outro é queda de um meteoro provocada por uma 'macumba'. Novamente, não é o sujeito do discurso que realiza diretamente a ação de matar.

Surge aí um pré-construído de religiões de matriz africana, desprestigiada no âmbito dos saberes de uma FD conservadora e de direita. Para Pêcheux, conforme formulado por Paul Henry, o pré-construído "designa o que remete a uma construção anterior, exterior, mas sempre independente, em oposição ao que é 'construído' pelo enunciado" (p. 89, 2009). Indursky, ao estudar o regime de repetibilidade que sustenta alguns dizeres, explica que "todo elemento de discurso que é produzido anteriormente em um outro discurso e independentemente é entendido como um pré-construído" (2011, p. 69). Ao recorrer ao interdiscurso, o sujeito traz para o fio do discurso elementos externos, explicitando, assim, a presença da exterioridade no discurso pela pré-existência do objeto do pensamento. Há duas formas de presença da exterioridade no discurso quando pensamos o pré-construído, conforme a autora. Há a modalidade do encaixe sintático e do discurso transverso como formas de apropriação do pré-construído, de retomadas, de repetições de já-ditos. No primeiro processo, os elementos externos que emergem no discurso apresentam marcas sintáticas que traem a presença do outro. Já pela modalidade do discurso transverso, o pré-construído emerge no fio do discurso como "retomada de saberes já-ditos em outro discurso, em outro lugar e cujo eco ressoa no discurso do sujeito" (INDURSKY, 2011, p. 69). Porém, trata-se de uma presença sem marcas linguísticas, a qual pode ser apreendida pela categoria da memória, pois "o discurso-outro entra de viés no discurso do sujeito, tangenciando-o e nele fazendo eco de algo que foi dito em outro lugar" (INDURSKY, 2011, p.70).

Retomando a análise da sd 9, temos que na linguagem popular, o termo macumba pode referir-se a rituais ou quaisquer manifestações das referidas religiões e também manifestações específicas que se realizam como feitiços, sortilégios, magias malígnas de modo geral. Esse pré-construído funciona aí mobilizando já ditos acerca de um modo negativo de significar essas religiões e suas práticas, por isso, quando emergem no discurso, são associadas ao mal, a fazer o mal a outrem. 
E, assim, podem ser um dos caminhos apontados para a concretização da punição imposta ao sujeito nordestino.

Disso, observamos que a pena de morte imposta ao sujeito nordestino, nesse discurso, é terceirizada, é transferida a outrem ou se cumpre de modo que o sujeito enunciador não realize a ação: que alguém mate, que uma doença mate, que um meteoro mate. $\mathrm{O}$ nordestino precisa ser punido, mas não é o sujeito enunciador quem aplicará a punição, a ele cabe o papel de impô-la e instigar a sua concretização. Com isso, é produzido um efeito de distanciamento do sujeito enunciador em relação aos movimentos de violências materializados em seu dizer. $\mathrm{O}$ que pode ser compreendido como um modo de minimizar o peso negativo desse discurso, pois, nessa perspectiva, o sujeito enunciador não realiza ações violentas, punitivas ou exterminadoras, ele 'apenas' produz um discurso que estimula esse modo de significar o resultado eleitoral e o sujeito nordestino. Esse é mais um caminho que nos leva a compreender que o discurso em pauta funciona como um discurso de ódio.

Além disso, esse movimento de punição funciona, no discurso, produzindo efeitos em cascata, tendo destinatários sucessivos. Só é possível observar esse efeito se considerarmos a posição de dizer em que se inscreve o sujeito enunciador e as condições de produção desse discurso. Vejamos esse funcionamento tomando a sequência 7 como exemplo.

Esta sequência repercute o resultado da eleição hostilizando os supostos eleitores da candidata vencedora e instigando sua punição ao clamar pela morte do sujeito nordestino. Baseia-se numa culpa já estabelecida: nesse processo discursivo já está definido quem é o sujeito responsável, agora a questão é puni-lo.

Ao agredir e buscar punir seus supostos eleitores, os efeitos de sentido produzidos nesse discurso se estendem à Presidenta, que passa a fazer parte dessa cadeia de rejeição e de punição. Então, o ódio ("mata esses nordestinos") tem duplo destinatário: os eleitores que, com seu voto, reelegeram Dilma e também a própria candidata reeleita. Com isso, está em funcionamento um movimento de rejeição, cuja raiz é a não aceitação do resultado eleitoral. Diante desse quadro, o enunciado em análise pode ser parafraseado na seguinte cadeia de significação:

- Mata esses nordestinos $\rightarrow$ 'mata' esse governo $\rightarrow$ 'mata' essa Presidenta $\rightarrow$ 'mata' tudo que contrarie os saberes da FD anti-Dilma

Discursivamente, essas relações de paráfrase funcionam como numa cadeia de punição dirigida aos saberes antagônicos à FD que regula esse dizer. Assim, 
o sujeito que ocupa uma posição de dizer oposta e tudo que se desdobra dessa posição é alvo desses efeitos de sentido.

Observando esse efeito, compreendemos que subjaz a esse movimento de punição outra cadeia de sentidos: a de rejeição, a qual produz um efeito de sustentação que permite que a punição possa ser instaurada nesse discurso. Tais efeitos de rejeição podem ser representados, parafrasticamente, da seguinte forma:

- Não aceito esses eleitores $\rightarrow$ não aceito esse governo eleito por eles $\rightarrow$ não aceito essa Presidenta eleita por eles $\rightarrow$ não aceito saberes opostos aos da FD anti-Dilma

Logo, como num movimento de polarização representado pelo par antagônico nós/eles, essa é a Presidenta deles, não é a nossa Presidenta. Nesse panorama maniqueísta o nós está no âmbito da FD anti-Dilma e o eles (a quem é dirigido o ódio, a rejeição e a punição) está no âmbito de uma FD antagônica. Sendo assim, através dessas cadeias de produção de sentido, todos os elementos envolvidos no acontecimento discursivizado (reeleição de Dilma) são abrangidos pela punição imposta.

Adiante, nossas reflexões voltam-se à sequência 6, pois consideramos que a mesma produz, de modo mais intenso, os efeitos de punição e de ódio ao sujeito nordestino que permeiam todo esse processo discursivo.

- sd 6 - Desejo do fundo do coração que sejam tomados pela desnutrição, que seus bebês nasçam acéfalos, que suas crianças tenham doenças que os médicos cubanos não consigam tratar, que o ebola chegue no Brasil pelo Nordeste e mate a todos! Só outra arca de Noé pra dar jeito!

Esse discurso retoma, do interdiscurso, um forte antagonismo já em circulação em nossa sociedade, dando continuidade a um processo conflituoso de significação do outro, conforme observamos ao abordar o efeito fundador dessa discursividade. No imaginário dos sujeitos inscritos na FD anti-dilma, os nordestinos são considerados a parcela da população brasileira que representa o baixo nível cultural e social, pessoas que sabotam "o trabalho construtivo, decente e elevado" (FONTES, 2008, p. 73), por isso merecem ser aniquiladas da espécie humana: "Só outra arca de Noé pra dar jeito!" (sd 6).

A menção à narrativa bíblica de Noé remete, interdiscursivamente, ao episódio de destruição do mundo e à salvação de poucos animais, um casal de cada espécie. Os nordestinos, então, não seriam dignos de ser salvos, já que não 
deveriam sequer existir. Por não merecerem existência, lhes são dirigidos desejos dos mais graves distúrbios de saúde: desnutrição, acefalia, doenças não curáveis, ebola etc. para que, com isso, todos sejam mortos e, enfim, outra Arca de Noé possa solucionar os problemas de nossa sociedade, extirpando os nordestinos da nação brasileira. Nesse funcionamento discursivo, percebemos a emergência do discurso religioso utilizado, paradoxalmente, como argumento para sustentar o ódio ao outro. No caso em análise, há referência a uma possibilidade de salvação da sociedade brasileira, a qual se realizaria com a aniquilação dos nordestinos, uma vez que a salvação em si seria a morte dessa parcela da população brasileira.

Nesse processo, ocorre um atravessamento do discurso religioso, por meio de um pré-construído. A narrativa bíblica de Noé é uma construção anterior, exterior e independente, ou seja, um pré-construído, que traz para o intradiscurso o discurso bíblico.

Nessa sequência discursiva, o discurso religioso irrompe no intradiscurso pela modalidade do discurso transverso e surge deslocado, sofre algumas alterações em seu processo de significação ao funcionar como uma das bases em que se funda o discurso de ódio dirigido aos nordestinos. Falamos de deslocamentos de sentidos porque esta narrativa bíblica não produz efeitos de ódio, discriminação ou violência. No entanto, quando destacada de seu contexto de produção e inserida num processo discursivo ancorado na polarização entre eu/outro, em que há uma relação hierarquizada entre superior/inferior, a salvação de cada espécie da fauna na narrativa bíblica transforma-se no extermínio de um grupo e na 'salvação' de outro.

Outro aspecto que acirra o antagonismo e o ódio materializados nesse discurso, reiterando a rejeição à Dilma, a suas políticas de governo e ao próprio governo, é observado no seguinte trecho: "[...] que suas crianças tenham doenças que os médicos cubanos não consigam tratar" (sd 6, grifamos).

Médicos cubanos foram trazidos para o Brasil no governo Dilma, a partir de 2013, através do programa Mais Médicos, para suprir a falta de profissionais em municípios do interior e em periferias ${ }^{11}$. Tal iniciativa do governo foi mal recebida por parte da população, da grande mídia, de alguns órgãos de classe de profissionais da área da saúde. Houve um forte movimento de boicote aos profissionais cubanos por parte de profissionais brasileiros. Instaurou-se, assim, uma polêmica em torno da presença de médicos cubanos no país. E, nesse contexto, a aceitação ou não do programa governamental e desses médicos foi significada atrelada à aceitação ou não do próprio governo Dilma.

11. Conferir em: < http://www.brasil.gov.br/saude/2013/08/mais-medicos-divulgada-a-lista-de-participantes $>$. 
Nessas condições de produção, da perspectiva do discurso da FD anti-Dilma, os médicos cubanos são fruto de uma política do governo Dilma, um governo ruim que fracassou e, assim como o governo e a Presidenta seriam ruins e fracassados, os 'seus' médicos cubanos também o seriam. Outro fator implicado nesse processo de significação é a aversão a posições políticas-ideológicas de orientação socialista, tal como a do regime vigente em Cuba. Faz eco nesse discurso a não aceitação de posições antagônicas, bem como a homogeneização do diferente, pois para o discurso em análise o governo de Dilma é igual ao governo cubano, sendo, por vezes, tratado como uma extensão de Cuba, conforme veremos na análise das sequências 11 e 12 .

Além disso, no funcionamento maniqueísta observado nesse discurso, o sujeito que se opõe aos sabres da FD anti-Dilma inscreve-se no domínio de saber da FD adversa: portanto, apoia as medidas do governo Dilma. Se as apoia, deve ser tratado apenas pelos médicos cubanos. Se tais médicos são tão ruins quanto o governo, o sujeito que deve ser tratado por esses médicos está fadado à morte. E, na expectativa de que essa cadeia de significação se cumpra, a morte do outro é desejada, esperada e significada como algo positivo para o sujeito enunciador. Nessa mesma direção funciona a menção do vírus do ebola, ou seja, expõe essa cadeia de significação do outro e da relação com a diferença como uma relação de ódio.

Diante disso, observamos que o ódio dirigido a um grupo de eleitores revela um desejo de aniquilar o outro que pensa diferente, que vota diferente. É um ódio que se dirige ao nordestino como uma espécie nociva.

\section{DA IMPOSIÇÃO DE UMA SOLUÇÃO PARA O CONFLITO}

O desfecho do processo de violências em análise é observado a partir de sequências que materializam a imposição de uma solução para o antagonismo discursivizado. Representam esse movimento as três últimas sequências que compõem nosso corpus: sd 10, sd 11 e sd 12. Vejamos a primeira: "O negócio é dividir o Brasil em 2... Dilma para o norte, nordeste e centro oeste...e Aécio para Sul e Sudeste... seria muito justo ... cada um ter o presidente que merece" (sd 10)

Após culpabilizar e punir os nordestinos, surge a solução para a situação do Brasil, uma vez que o conflito em si já não pode mais ser solucionado, posto que o sujeito nordestino é significado, nesse domínio de saber, como "caso perdido". Já foi declarado culpado, já foi punido, mas isso não é o suficiente. Para o sujeito enunciador, o nordestino não tem possibilidade de redenção, porque 
sua caracterização negativa é sua própria condição de existência, não mudará. É dizer, nesse discurso, o nordestino vai ser sempre burro, maldito, câncer, idiota; vai ser sempre o sujeito responsável pela destruição do país. Então, nesse processo de significação do nordestino, o único meio de evitar que ele continue causando prejuízos à nação é dividir o Brasil e os brasileiros. $\mathrm{O}$ único meio de evitar que o funcionamento democrático prejudique a FD anti-dilma, é excluir o outro, é instaurar uma democracia apenas para os saberes dessa rede discursiva, banindo as diferenças.

Essa divisão dos brasileiros em dois grupos antagônicos corresponde à divisão entre sujeitos que se filiam aos saberes da FD anti-dilma e os que se filiam à FD adversa (que poderia ser considerada pró-Dilma): "Dilma para o norte, nordeste e centro oeste...e Aécio para Sul e Sudeste". Cada rede discursiva com seu presidente, com sua democracia. O conflito polariza a população brasileira conforme a aceitação ou não do resultado eleitoral e a solução mantém a polarização, mas suspende o conflito, pois suspende o contato entre os grupos.

Esse mesmo modo de significar o conflito também foi materializado em imagens do mapa político do Brasil: são mapas redefinidos ou redesenhados de acordo com os saberes dessa FD. Os efeitos de sentido são produzidos na mesma direção que observamos até aqui nesse processo discursivo. Ou seja, tais materialidades põem em movimento efeitos de segregação/separação dos brasileiros, seguindo a dicotomia hierarquizante nós/eles. Eis os mapas:

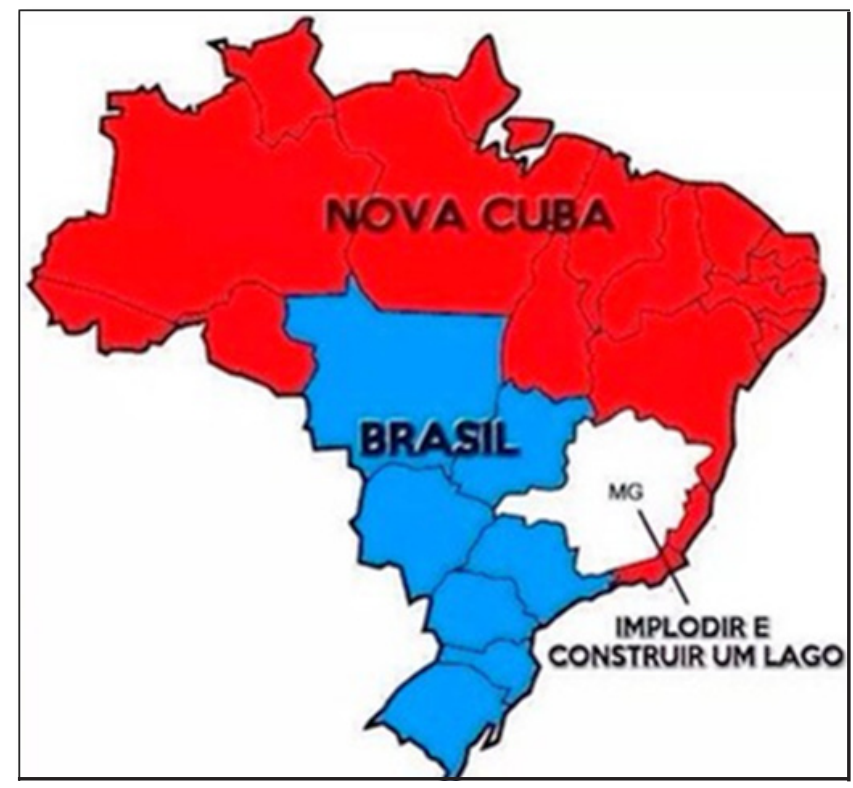




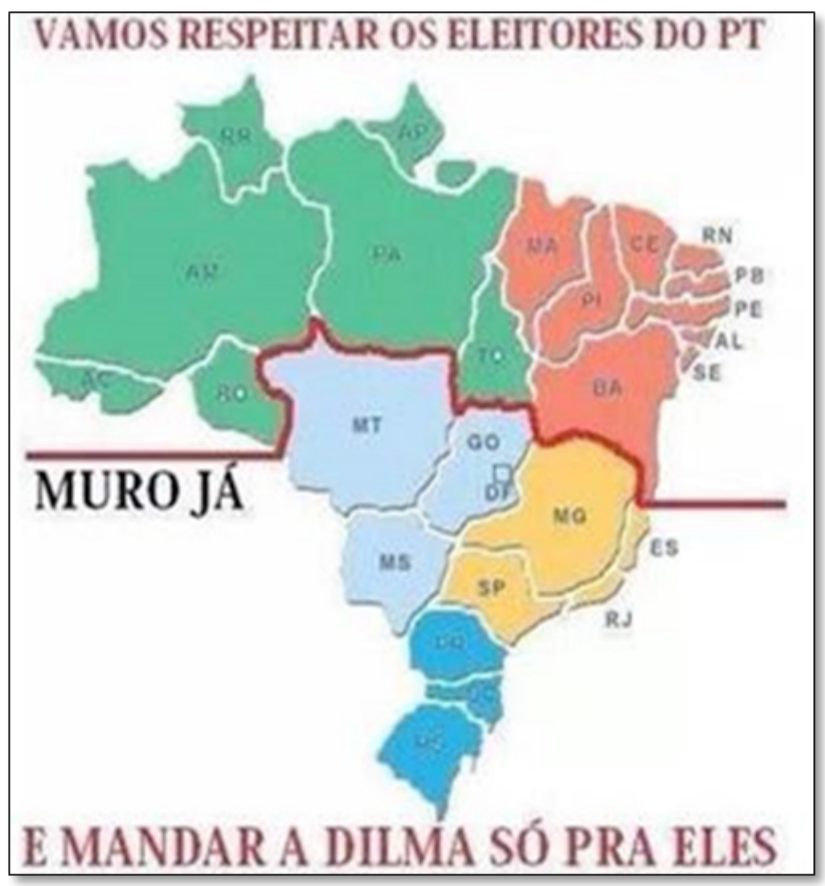

Subjaz às sequências 11 e 12 o pressuposto de que a origem dos problemas da região Sul e Sudeste do Brasil foi acolher os nordestinos e os nortistas. Partindo dessa perspectiva, a solução está sendo apontada nos mapas: segregar, apartar esse outro, (tido como subdesenvolvido) da parcela de brasileiros pretensamente desenvolvida. A solução seria demarcar o espaço do desenvolvimento e o do subdesenvolvimento e declarar que, numa atitude separatista, cada povo ficasse no espaço que lhe coubesse e tivesse o Presidente que escolheu e que merece (cf. sd 10 e sd 12). Assim, o Brasil seria composto por dois 'povos' distintos: sulistas e nordestinos. A separação desses povos é tida, então, como uma necessidade no âmbito desse discurso.

Tais mapas revelam o imaginário de não igualdade entre as parcelas da população brasileira apresentadas como antagônicas nesse discurso. Da exigência de separação desses grupos, resulta uma designação diferente para os espaços que cabem a cada povo (sd 10): Brasil e Nova cuba. Nesse processo discursivo, a dicotomia eu/outro desdobra-se em dois espaços demarcados geograficamente: Norte para os que não partilham das mesmas filiações do sujeito enunciador e Sul para aqueles que se inserem na mesma rede discursiva desse sujeito. Para esse outro corresponde um outro espaço: Nova Cuba, enquanto o sujeito do discurso 
permaneceria no Brasil (sd 11). Um Brasil demarcado de modo a incluir em seus limites apenas os sujeitos inscritos na FD em que se inscreve o sujeito enunciador.

Os nordestinos, a parcela dos não iguais, deixariam de ser considerados brasileiros e passariam a ser denominados como 'novos cubanos'(sd 11). Cada parcela é identificada, ainda, com uma cor, a qual remete ao candidato que corresponde a cada povo: vermelho, de Dilma Rousseff, para os nordestinos, e azul, de Aécio Neves, para os sulistas.

A associação de cada grupo a uma dessas cores provém de já-ditos, de sentidos que habitam o interdiscurso. O vermelho faz ressoar dois outros discursos, pois remete ao vermelho do PT, partido da Presidenta Dilma, e ao vermelho símbolo do ideário comunista, considerado ainda vigente em Cuba. Com isso, é intensificada a relação dos saberes da FD adversa com Cuba, daí surge a denominação de 'Nova Cuba' para o espaço geográfico que deveria concentrar apenas os sujeitos inscritos no seu domínio de saber. Com isso, o sujeito enunciador significa a rede discursiva antagônica como sendo de ordem comunista, de orientação política-ideológica de esquerda.

Já o azul faz ressoar a cor símbolo do partido de Aécio Neves, PSDB, sendo uma das cores mais utilizadas em sua campanha de marketing eleitoral em 2014. Mas, além disso, considerando que nessa materialidade é discursivizada a relação antagônica entre duas FDs, ao colorir o espaço que caberia aos sujeitos filiados à FD anti-Dilma com a cor azul, o sujeito enunciador significa essa rede discursiva numa direção oposta à FD pró-Dilma. Ou seja, se o vermelho é associado a saberes de orientação socialista, o azul seria regulado por saberes de ordem capitalista e de orientação política-ideológica de direita.

Essas relações que os discursos estabelecem com a exterioridade são recuperadas pela categoria da memória discursiva: funcionam como retomadas de dizeres interdiscursivos sem deixar marcas linguísticas. São pré-construídos que emergem no discurso em análise.

Temos, ainda, uma terceira parcela de brasileiros, inferior à parcela dos não iguais (nordestinos), pois merece ser destruída. São os mineiros. Assim como os nordestinos, os mineiros são separados do "Brasil" porque boa parte deles assumiu uma posição político-ideológica divergente em relação aos saberes da FD1 e, também, pelo fato de ter sido a única parcela da população brasileira já governada pelo candidato Aécio Neves e que, mesmo assim, em sua maioria, rejeitou a possibilidade de ser governada novamente por esse candidato. Com isso, os mineiros fortaleceram a candidata vencedora, colaborando para sua vitória e enfraquecendo o candidato Aécio por ter sido rejeitado 'em casa'. Na perspectiva 
desse discurso e conforme representado na sd 11, os mineiros opõem-se aos saberes da FD1 por esses dois motivos e merecem mais do que a segregação: precisam ser aniquilados do mapa do Brasil - "implodir e construir um lago" (sd 11). Com isso, em nosso ponto de vista, o discurso de ódio desta FD atinge seu ápice.

É nessa direção de sentido que as relações de antagonismo são discursivizadas no processo discursivo da FD1. A diferença, a divergência surge como algo inconciliável, incompatível com a (con)vivência coletiva, de forma que o outro é o indesejável, não podendo, nessa perspectiva, ocupar os mesmos espaços que o sujeito filiado aos saberes da FD1.

Na sequência 12, também é representada uma proposta de divisão do Brasil, mas não em duas nações diferentes. Aqui, tal como na sd 11, são representadas as parcelas dos iguais (sulistas/sujeitos filiados à FD1) e dos não iguais (nordestinos/ sujeitos filiados à FD2), entretanto, a divisão proposta como solução para o antagonismo vivenciado consiste na construção de um muro: "MURO JÁ" (sd 12).

Esse enunciado, assim como as cores azul e vermelho, faz ressoar já-ditos, como pré-construídos provenientes do interdiscurso. Na história política brasileira, o advérbio já remete, dentre outros, a dizeres como 'diretas já'12, 'impeachment já'13. Surge associado a eventos em que a população brasileira se mobilizou massivamente para reivindicar seus direitos em momentos políticos conturbados (ditadura militar e investigações de corrupção na cúpula do Poder Executivo em 1992). Está marcado, ainda, pelo êxito das reivindicações ancoradas em tais bordões, sugerindo veracidade e legitimidade a esses movimentos, ou seja, envolvendo o adverbio já em um processo de significação positivo em nossa história política.

No contexto da sd em análise, esse advérbio forma um novo bordão: "muro já". Entendemos que o pré-construído emerge aí pela modalidade do encaixe sintático, pelo uso do mesmo advérbio para formar um novo bordão.

O termo muro também remonta a já-ditos, também faz ressoar outros dizeres no intradiscurso, apreendidos pela categoria da memória discursiva. A ideia de muro como instrumento para separar polos de um mesmo conjunto ou de conjuntos diferentes remete ao Muro de Berlim, no período da Guerra Fria, e, também, ao muro que separa Estados Unidos e México contemporaneamente.

O muro, no caso em pauta, impede o estabelecimento de laços entre sujeitos, dá existência física à fronteira, materializando-a como uma barreira e não um local

12. O movimento das "diretas já" ocorreu em 1983 e 1984, no fim do período da ditadura militar brasileira, consistiu na reivindicação por eleições presidenciais diretas.

13. Impeacbment já foi um bordão utilizado, em 1992, em protestos dos 'caras pintadas' contra o então Presidente Fernando Collor de Melo. 
de trocas, fluxos, misturas. Torna-se um impedimento à passagem, é um símbolo de separação, de exclusão, de banimento. Com o muro, o indesejável é banido, é impedido de transgredir a fronteira que demarca os limites entre nós/eles, ou entre sujeitos inscritos na FD anti-Dilma e sujeitos inscritos na FD que lhe é antagônica.

Por fim, observamos que nos dois mapas a divisão proposta para o Brasil é a mesma: Aécio para as regiões Sul, Sudeste e Centro-Oeste e Dilma para as regiões Norte e Nordeste. O tratamento homogeneizante dispensado aos elementos que compõem a dicotomia em que se baseia (nós/eles, sulistas/nordestinos) também é o mesmo. Nesse discurso, os nordestinos são tratados de forma uniformizante, como se todos os brasileiros oriundos dessa região partilhassem as mesmas filiações. Como se todos assumissem a mesma posição político-ideológica e a mesma posição de dizer. Funcionando como uma via de mão dupla, os 'sulistas' também são considerados de maneira homogênea: como se todos os brasileiros que vivem nessa região partilhassem a mesma rede de filiações. Como se todos votassem igual e todos fossem anti-Dilma.

O maniqueísmo que subjaz ao discurso em análise funda-se na ilusão da homogeneidade, na desconsideração das diferenças internas e externas. Por isso, cada grupo, representado no mapa da sd 11, surge pintado com uma única cor, ignorando as possíveis nuances de azul e de vermelho em cada um, ou mesmo os tons avermelhados que podem conviver em meio ao universo dos saberes da FD anti-Dilma (representado pela cor azul). E, do mesmo modo, ignora os tons azulados que podem estar presentes no universo dos saberes da FD adversa (representado pela cor vermelha).

O modo pelo qual a dicotomia em análise é significada, no âmbito do discurso da FD anti-Dilma, aponta para um desfecho extremo: a única solução para esse embate é separar o Brasil em dois, pois as forças antagônicas em confronto não são passíveis de ser conciliadas. Separar é, portanto, o último degrau na escala de violências contra o outro materializada nesse discurso.

Como último passo em nosso gesto analítico, observamos um excesso discursivo que perpassa todo o discurso de ódio produzido no âmbito da FD anti-Dilma. Entendemos o termo excesso tal como propõe Ernst (2009) - como princípio geral que orienta a criação do gesto de interpretação frente aos propósitos de análise. Para a autora, o excesso funciona como "estratégia discursiva que se caracteriza por aquilo que está demasiadamente presente no discurso" (2009, p. 4). Tal categoria de análise opera nos níveis intradiscursivo e interdiscursivo. Ou seja, podemos observar o excesso na linearidade do discurso por meio do uso de incisas, de intensificadores ou pelas repetições de palavras ou expressões 
e orações. E, também, podemos pensar o excesso no plano interdiscursivo como "reiteração incessante de determinados saberes interdiscursivos que tomam formas diferentes no intradiscurso, mas mantêm os mesmos pressupostos ideológicos" (ERNST, 2009, p. 4, grifamos).

Em nossa análise observamos o excesso operando no nível interdiscursivo. O discurso de ódio aos nordestinos da FD anti-Dilma é saturado de certos saberes: insiste na repetição de efeitos de não aceitação do outro, os quais já circulam em nossa sociedade desde a década de 1930. O discurso analisado retoma esses saberes e (re)atualiza-os, significando o nordestino como se fosse um outro que, além de ser inferior e responsável pelos males do país, não deve sequer participar da vida política da nação. Esse excesso que perpassa todo o discurso de ódio analisado, funcionando como uma estratégia para legitimar os saberes intolerantes ao outro e instigar a ampliação de seu alcance; bem como para insistir na dominância dos saberes da FD em que se inscreve o sujeito enunciador.

\section{CONSIDERAÇÕES FINAIS}

Os funcionamentos discursivos analisados apontam para um horizonte de significação em que liberdade e igualdade não são considerados universais no âmbito da FD anti-dilma. Neste discurso, apresentam-se como direitos fundamentais apenas para uma parcela da população: para os sujeitos que não colaboraram para a reeleição de Dilma Rousseff. Aos demais brasileiros resta a desqualificação, a posição expiatória, a violência, ao invés do reconhecimento de direitos fundamentais. É desse modo que se constrói a relação hierarquizada entre o eu, sujeito inscrito na FD anti-Dilma, e o outro, sujeito que não se filia a esses saberes. Essa forma de relação com o outro é subjacente ao discurso de ódio, que se produz num regime de repetibilidade de saberes que significam o outro como inferior e, pela repetição, atuam na estabilização das relações sociais de dominação, fazendo funcionar a ideologia dominante. É este funcionamento discursivo que propomos definir como discurso de ódio. Esse modo de significação do antagonismo em pauta consolida, neste imaginário, o Brasil e os brasileiros da FD1 e o Brasil e os brasileiros da FD2, de modo homogeneizante. Assim, emerge o ódio dirigido ao eleitor nordestino, o qual acaba produzindo um outro efeito de sentido: o ódio ao próprio regime democrático.

Acerca dos efeitos de ódio à democracia, pensamos, com Rancière (2014, p. 10), que se trata do ódio ao respeito às diferenças, aos direitos das minorias, às políticas afirmativas. Para o autor, a democracia surge como fator de mediação da 
relação entre a oligarquia e o povo: mediando a relação tensa entre dominados e dominadores.

Rancière, a partir de um retrospecto da ideia de democracia, de suas práticas e da discussão acerca das incongruências dos regimes modernos, entende que, atualmente, vivemos em Estados de Direito Oligárquicos, os quais são construídos a partir da "apropriação da coisa pública por uma sólida aliança entre a oligarquia estatal e a econômica" (2014, p. 93). Assim, nesse contexto, o ódio à democracia nasce da intolerância das elites, e seus porta-vozes

dizem que ela [democracia] já é real demais. Nenhum se queixa das instituições que dizem encarnar o poder do povo nem propõe medidas para restringir esse poder. É do povo e de seus costumes que eles se queixam, não das instituições de seu poder. Para eles, a democracia não é uma forma de governo corrompida, mas uma crise da civilização que afeta a sociedade e o Estado através dela (RANCIÈRE, 2014, p. 10).

O autor explica que as elites não conseguem se adaptar à democracia e seus consectários para a vida em sociedade, para um convívio democrático. As elites não toleram os valores democráticos, por isso "os males de que sofrem nossas 'democracias' estão ligados em primeiro lugar ao apetite insaciável dos oligarcas" (RANCIÈRE, 2014, p. 94). É para esse caminho que se orienta o discurso em análise como um discurso de ódio.

\section{REFERÊNCIAS}

BRASIL. Código Civil. Disponível em: http://www.planalto.gov.br/ccivil_03/leis/2002/ L10406.htm. Acesso em: 23 out. 2016.

BRASIL. Constituição, 1988. Disponível em: http://www.planalto.gov.br/ccivil_03/ Constituicao/Constituicao.htm. Acesso em: 23 mar. 2014.

BOBBIO, N. (2014). Qual democracia? São Paulo: Edições Loyola, 2014.

BRUGGER, W. (2007). Proibição ou Proteção do Discurso do Ódio? Algumas Observações sobre o Direito Alemão e o Americano. Revista de Direito Público, Brasilia, v. 15, n. 117, jan-mar. 2007.

ERNST-PEREIRA, A. (2015). A falta, o excesso e o estranbamento na constituição/interpretação do corpus discursivo. 2009. Disponível em: http://www.ufrgs.br/analisedodiscurso/ anaisdosead/4SEAD/SIMPOSIOS/AracyErnstPereira.pdf. Acesso em: 03 mar. 2015. 
FONTES, P. (2008). Um nordeste em São Paulo: trabalhadores migrantes em São Miguel Paulista (1945-66). São Paulo: FGV Editora.

INDURSKY, F. (2011). A memória na cena do discurso. In: INDURSKY, F.; MITTMANN, S.; FERREIRA, M. C. L. (orgs.). Memória na/da análise do discurso. Campinas: Mercado de Letras.

MALDIDIER, D. (2003). A inquietação do discurso. Campinas: Pontes.

ORLANDI, E. P. (2013). Análise de Discurso - Princípios e Procedimentos. Campinas: Pontes.

ORLANDI, E. P. (2013). (2011). A linguagem e seu funcionamento: as formas do discurso. Campinas: Pontes.

ORLANDI, E. P. (2013). (2003). Vão surgindo sentidos. In: ORLANDI, E. (Org.). Discurso Fundador - A formação do país e a construção da identidade nacional. Campinas: Pontes.

PECHEUX, Michel (2010). Análise automática do discurso (AAD-69). In: GADET, Françoise; HAK, Tony (Org.). Por uma análise automática do discurso- uma introdução à obra de Pêchuex. Campinas: Editora da Unicamp.

PECHEUX, Michel (2009). Semântica e Discurso. Campinas: Editora da Unicamp.

RANCIERE, J. (2014). O ódio a democracia. São Paulo: Boitempo.

SARMENTO, D. (2006). A liberdade de expressão e o problema do bate speech. Rio de Janeiro.

SARMENTO, D. (2016). Dignidade da pessoa bumana - conteúdo, trajetória e metodologia. Belo Horizonte: Fórum.

TOURAINE, A. (1996). O que é a democracia? Petrópolis: Vozes.

TOURAINE, A. (1998). Poderemos viver juntos? Iguais e diferentes. Petrópolis: Vozes.

ZIZEK, S. (2014). Violência: seis reflexões laterais. São Paulo: Boitempo.

Recebido: $12 / 03 / 2018$

Aceito: 9/07/2018 